\title{
BANGgAI IN SHIPPING AND TRADING IN THE EASTERN REGION OF SULAWESI IN THE 19TH CENTURY
}

\author{
Hasanuddin \\ Balai Pelestarian Nilai Budaya Sulawesi Utara \\ Jl. Katamso Bumi Beringin, Manado 95113, Indonesia \\ anwar_hasanuddin@yahoo.com
}

Received: 16/01/2018; revisions: 11/03 - 14/06/2018; accepted: 05/07/2018

Published online: 31/07/2018

\begin{abstract}
Banggai has a strategic role in the shipping and trading networks in eastern Sulawesi. Its geographical location connects between Gorontalo, Tomini Bay, Ternate, Buton, and Makassar. This condition is reinforced by the availability of various commodities, such as iron ore, sea cucumber (teripang), sea turtle scales, bird's nest, sandalwood, resin, rattan, and copra. This article looks at Banggai and its role in trade and shipping in the eastern region of Sulawesi in the $19^{\text {th }}$ century. This article aims to describe the condition of Banggai which includes among others; Banggai position in the archipelago shipping lanes, dynamics of inter-island trade, dynamics and activities of pirates in the Banggai region, and the presence of settlements in the form of merchant and immigrant villages. This study used historical method of archive search and literature study by collecting historical data, then describing an event into its parts in order to understand the shipping and trading of Banggai in the $19^{\text {th }}$ century. This article proves that Banggai maritime network has become an important factor in integration of the waters of eastern Sulawesi, both in terms of community and inter-royal and power connections. The traders and migrants from Bugis, Buton, Gorontalo, Mandar, Bajo, China, and Arab became the forming factor of a multi-faceted community in Banggai. This condition gave birth to a new situation through communication links between traders and immigrants with local residents which have shown a dynamic cultural process with different backgrounds. This situation creates the integration of eastern Indonesia and encourages development of shipping and trading networks in eastern Sulawesi.
\end{abstract}

Keywords: Shipping; Trading; Merchant Village; Banggai

\section{INTRODUCTION}

The study of shipping and trading lanes is an important point that has not been widely studied. These days the study of Indonesian history is more dominated by events occurring in the political life of monarchs in the land-oriented archipelago. Although there have been several maritime history studies with the theme of shipping, but the focus on eastern coast of Sulawesi is very rarely written. Lapian (1987) has initiated the study of the Sulawesi Sea region of Orang Laut, Bajak Laut, Raja Laut, which was then published in a printed book in 2011. There is a study on Buton in contact with Banggai but has not yet been explored (Zuhdi, 2010). Marine studies are increasingly needed as Indonesia is a region of thousands of large and small islands. This factor causes Indonesia to be included in the largest archipelagic country in the world (Kusumoprojo, 2009: 46). This condition affects the condition of the people who inhabit Indonesia territory, thus emerging various ethnic groups that have their own characteristics both in terms of tradition and social life patterns. Indonesia territory, which is mostly bordered by the sea, causes some people to earn their living from the sea.

The Indonesians begin to understand significance of the maritime region, suggesting that although the kingdoms were scattered across the archipelago for centuries, yet economically, socio-culturally, and politically have joined or combined in larger units (Lapian, 2008: 1). The merger can serve as a foundation in reinforcing Indonesian glory as a maritime nation living in an archipelagic country. According to Lapian (2011: 2), it is mandatory and top priority. Viewed from the perspective of maritime, Indonesia is the island of collective memory, yet many 'neglected' historical islands (Zuhdi, 2014).

Banggai is located in the eastern part of Sulawesi Island and faces the Maluku Sea, Tomini Bay, and Tolo Bay/Banda Sea. Banggai is a royal territory that successfully absorbs various communication links 


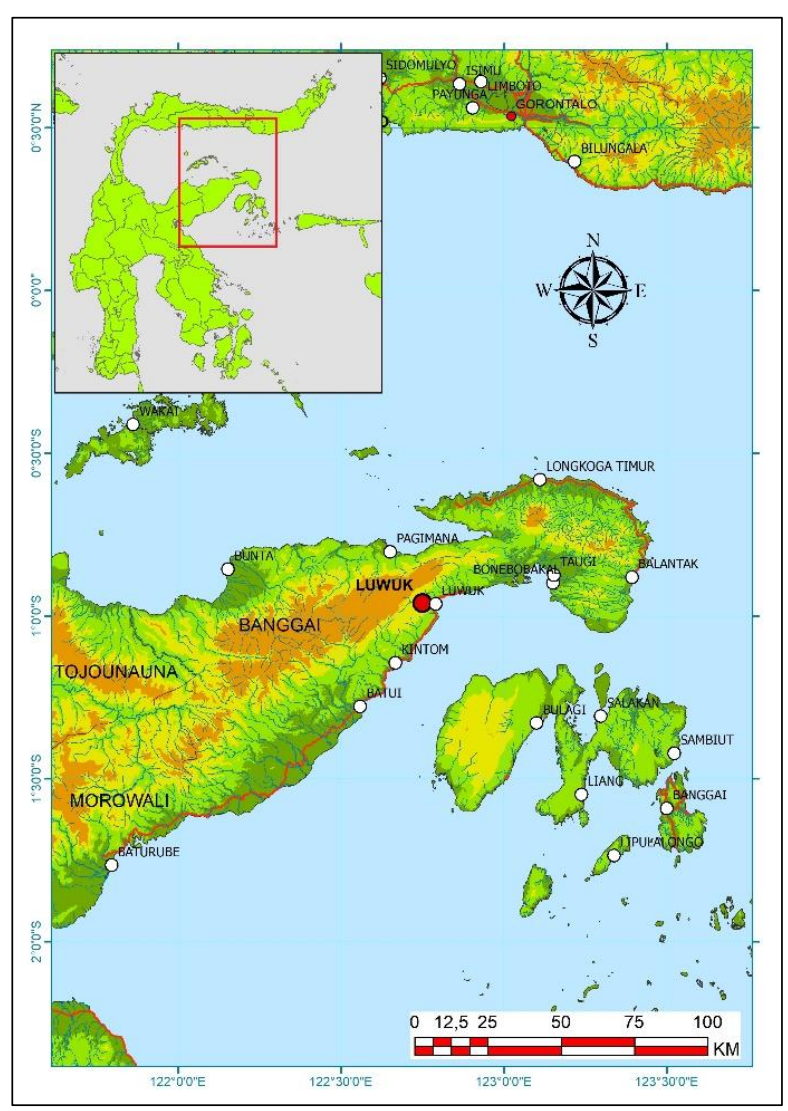

Figure 1. Map of Banggai Region

(Source: Basemap of Badan Informasi Geospasial, 2018)

through culture and power with the surrounding area, among others, Ternate, Gowa, Bone, Mandar, Wajo, Boalemo, Gorontalo, Bajo, Buton, Bungku, Parigi and Togian Islands. In fact, Banggai port in Banggai Laut Regency has a bigger role than the surrounding area, including Salakan port in Banggai Kepulauan Regency, Taliabu port, and Sula in North Maluku. It is undeniable that Banggai political dynamics have been influenced by maritime trading factors in the business competition and power of Ternate-Makassar-Bone. In the dynamics of archipelago history, Banggai seems marginalized despite having succeeded in establishing an inter-island shipping interactive connection. This shipping traffic correlation is the main factor that Banggai has progressed in its trade

Considering the strategic and open location of Banggai, then it become the destination of traders and immigrants. Referring to the opinion of Anthony Reid (2008) that the role of foreigners can be classified into two forms, namely; first, as merchant-adventurer cooperate with merchant-aristocrats, and sometimes they become political leaders. Usually, they have the capital of wealth, weapons, boats, and science. Second, in some cases foreigners can become magic-mediators among traditional societies. This view can also be found in Banggai and its connection with foreigner traders (Reid, 2008: 251-266). Banggai relationship with other areas was proposed by Maria J. Schouten (2004) in her study to perceive the connection between Minahasa and

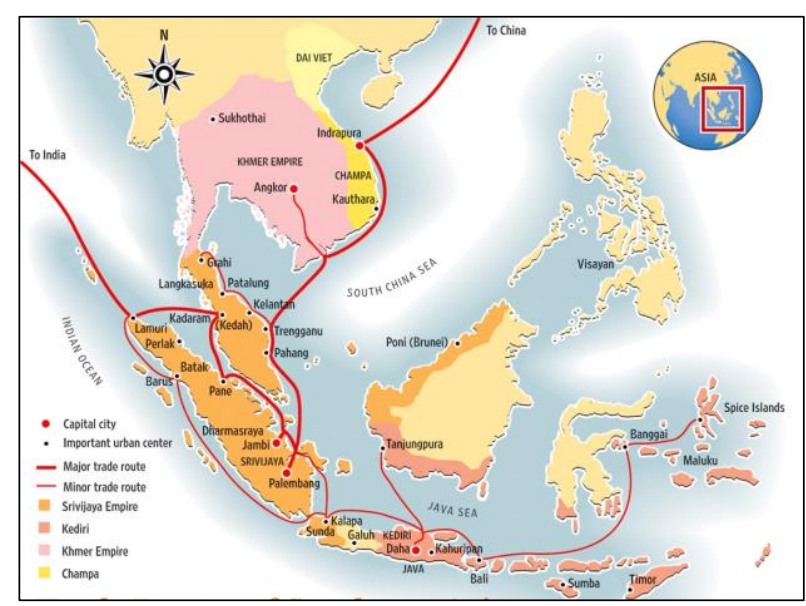

Figure 2. Map of Banggai in Shipping and Trading Routes in Southeast Asia in the $12^{\text {th }}$ and $13^{\text {th }}$ centuries (Source: Kartapranata, 2008)

other regions in the archipelago. She views the importance of perceiving inter-regional relationships using concept of 'center' and 'periphery' in understanding both correlations. Correlation of center-periphery is usually defined in terms of geographic, economic or power relation. However, this definition may also depend on cultural and social factors (Schouten, 2004: 213-235)

Some sources explain that Banggai was well-known in the $14^{\text {th }}$ century. The main source is found in the Nāgarakrtāgama manuscript written by Mpu Prapanca in 1287 Saka (1365 AD). In the Nāgarakrtāgama manuscripts, pupuh 14 stanzas 5 mentioned that "Banggawi" refers to Banggai, categorized as saka sanusa nusa or island areas (Riana, 2009: 102; Velthoen, 2002: 63). In 1000-1300 AD, and the 1304 record noted an existence of trade relations with China in producing major ceramic materials for Banggai, as well as trade relations with Maluku (Velthoen, 2002: 62). Banggai was well-known as an iron exporting region and became an important commodity in those days, there was an indication that iron in the Majapahit kingdom was imported from Banggai (Reid, 1992; Velthoen, 2002: 63).

In the $16^{\text {th }}$ century, Banggai controlled iron trade and was presumably the main export product originating from Tobungku and Mori (Henley, 2005: 34). They were all conquered by the Sultanate of Ternate (ANRI, 1980: 11-12). The Buginese and Makassarese had long been known to be skillful blacksmith and coppersmith. The iron raw materials they used did not only come from Luwu, but also from Banggai (Pelras, 2011: 18). Several explanations stated that Banggai is one of the kingdoms once dominated by Gowa (Abdurrahman, 2012: 89; Rochayati, 2010: 11). European sources often note that in the eastern region of Sulawesi in the $19^{\text {th }}$ century, there were three important developed kingdoms and had strong orientation in the maritime world: Buton, Tobungku, and Banggai (Velthoen, 2002: 5). 
The progress of trade in Banggai itself was determined by an existence of major trading commodities such as iron products, sea cucumbers, sea turtle scales, bird's nests, seashells, wood, and copra. The availability of these commodities makes Banggai an important area and attracts traders from Bugis, Gorontalo, Mandar, Ternate, Chinese, Arabs, and other foreign traders to conduct trading activities (Paulus, 1917: 139). In addition, the appearance of Tobelo and Mindanao pirates actively involved in piracy in the waters of the Banggai Islands participated in changing the dynamics of shipping and trading in the eastern part of Sulawesi. According to Lapian (2011), pirates are referred to as those who commit acts of violence at sea, without being authorized by the government in committing acts of piracy (Lapian, 2011: 163).

Communication link through shipping and trading is highly significant as communication channels attract merchants from different ethnic groups to settle and establish new settlements in Banggai. This factor creates an interaction between local people and traders as migrants interacting with each other and has an important role in the progress of the Banggai community. Merchants carry their ideologies, belief systems, political systems, and other cultural elements such as customs, art, literature, economic ethos, technology, and so on. This condition allows the birth of a new situation, or from a historical perspective as a consequence of the past situation as a result of intensive communication between traders and local people, thus it results in forming a pluralistic social community characterized by a dynamic cultural process.

In the above framework, it is important to bring up the role of Banggai in shipping and trading networks in eastern Sulawesi in the $19^{\text {th }}$ century. In view of previous studies with various arguments, including C. Bosscher and P.A. Matthijssen. (1854). "Schetsen van de rijken van Tomboekoe en Banggai, op den oostkust van Celebes," was a report of Ternate Resident. Bosscher and Matthijssen discussed the position of Banggai under the control of Ternate, but received supervision from the Dutch colonial. This report discussed more about Banggai political issues in the form of King Banggai rule of transfer of power and delivery of Banggai tribute to Ternate. Similarly, Dormeier (1947) in "Banggaisch Adatrecht" divided the Kingdom of Banggai into three regions, which are archipel refers to the islands region; vaste-wal (the mainland of Sulawesi) for the islanders call it "big land" which is a vast land area; and vogelkop or the head of birds, often referred to by officials of the Dutch colonial government as a land area that resembles a mushroom form. Dormeier reviews the posthouder placement in Banggai by the Ternate Resident to further facilitate oversight over the power of Banggai Kingdom. In addition, it is required to review the life of Banggai residents, especially early $20^{\text {th }}$ century concerning the formation of Luwuk area, and the formation of new forced villages.

This article reviews the role of Banggai in the $19^{\text {th }}$ century shipping and trading, in order to complement the range of studies on Banggai. Therefore, there are four main questions to answer. First, how the Banggai shipping lanes can be created and maintained by the merging of various ethnic; second, how inter-island trade gives dynamics in the process of integration and development of Banggai as a transit or connecting area; third, how the correlation between regions then encourage the appearance of pirates in the region, and fourth, how the development of shipping and trading network in Banggai. This article aims to understand that the Banggai maritime network is an important factor in integration of the waters of eastern Sulawesi, both in terms of community and inter-royal and power connection. Merchants and settlers become a community-building factor in Banggai. Through communication relationships between merchants and the kingdom it has shown a dynamic cultural process. This situation then created integration of the eastern region of Indonesia, and encouraged the progress of shipping and trading networks in the eastern region of Sulawesi.

\section{METHODS}

This study uses the method of historical science, which is through several stages; the first is to collect historical data (heuristics) by the process of finding historical sources. This period of study included the Dutch colonial period, the primary sources collected in the form of archives from the National Archives of the Republic of Indonesia (ANRI) such as archives, Koloniaal Verslag (KV), agreements or contracts with the Dutch colonial, and newspapers. The secondary sources are books of study on shipping and trading in Banggai. The primary sources that have been collected must be rectified, since the starting point of all historical work is to recognize the use of both primary and secondary sources (Gottshalk, 1986: 35-40). In addition, main basis of historical method is the process of handling historical evidences appropriate to the subject matter to be written. It can be archives and private letters. These evidences are reviewed and then considered in their conformity to the subject matter (Frederick \& Soeroto, 1984: 13-14). This step is carried out considering that each description does not escape subjective meaning. In addition, it requires criticism of sources, both in its authenticity or validity as external criticism as well as credibility of the source as an internal critic (Kuntowijoyo, 1995: 100). Furthermore, it needs interpretation by arranging, linking and explaining the data related to the studied problems to be a historiography (Kartodirdjo, 2014: 1-2). 


\section{RESUlt AND DiscusSion Shipping Line}

Commercial shipping activities are more influenced by wind conditions. The wind system plays an important role in the period, that shipping technology relies heavily on wind power. The seasonal winds that change direction consistently in every half year have created important factor to the shipping and trading. The role of the seasonal wind gives the sailors and merchants the knowledge to calculate their activities appropriately according to the consistent rhythm of the wind exchange. The discovery of western and eastern wind systems has provided the possibility of developing eastern and eastern shipping lanes regularly (Kartodirdjo, 1993: 1-2).

Monsoon winds cannot only affect the changing seasons but also connection of commercial shipping lines. The northwest monsoon is usually used by merchants in the western area, such as Malacca, Batavia, Surabaya and Makassar to sail eastward through Kendari, Buton Island, to Tolo Bay, Banggai Island, Tomini Bay, Gorontalo and to the Maluku Islands as the spice islands. Similarly, the return from Maluku to Banggai generally uses the northeast monsoon wind, which blows from May to September. This situation allows for a commercial relationship between Banggai and other ports in the Tomini Bay area, as well as trade centers in Ternate, Makassar, and Batavia.

Shipping from outside Banggai Island can enter Banggai Island by three directions. First, going from the north to the South China Sea through the Sulu Sea, then enters the Maluku Sea. Second, taking the eastern route through the voyage of the Pacific Ocean and going to the Maluku Sea. Third, the Java Sea connects the Flores Sea to Kendari, Tolo Bay and enters Banggai Island. Bugin traders who travel to Maluku are conducted in December and March, by shipping in the direction of the west monsoon. Depart from the east coast of South Sulawesi to the northern route through Kendari, Tolo Bay, Banggai Island, Tomini Bay, Ternate, North Halmahera, and Papua (Pelras et al., 2006: 363). Commercial shipping links with port areas particularly in Banggai are conducted by both indigenous and foreign traders. Buginese merchants perform cruise activities using padewakang and panlarij vessels.

Bugis voyages are mostly developed by sailors from Bone who settled in Cendrana, Bajoe, and Kajuara. In addition to Bone sailors, Wajo sailors who sailed from Lake Tempe or Cendrana River sailed from their own small ports in Doping and Pineki to Makassar, where the Wajo people had their own significant community (Pelras et al., 2006: 303). Bone sailors voyage to Banggai Island can go through the eastern part to Kabaena Strait towards Muna, continue to Buton then going to north to Kendari, continue to Salabangka to Bungku, then to
Teluk Tolo entering Banggai Island. Similarly, Wajo sailors through the southern route to the Selayar Strait, then east through the Kabaena Strait to Muna Island and Buton Island, then north to Kendari to Salabangka to Bungku to Teluk Tolo entering Banggai Island. Their trading activities are more concentrated on inter-island shipping. This was apparent in 1828, a stream of boats coming and departing from Gorontalo to Banggai (ANRI, 1976).

Despite the decline, it is interesting to note that in 1840 it was reported that about 20 to 30 Bugis sailboats (padewakang) visited Banggai, and annually contained iron and cucumber trade commodities (Henley, 2005: 458). For the sailor shipping from Mandar to Banggai generally use the northern path through the Makassar Strait towards Donggala. Then it proceeds to the northern voyage entering Tambu Bay east of Kasimbar. Once arrived in Kasimbar, it goes to the north to Moutong which is the power base of Mandar. The shipping is proceed to the Togian Islands to Ampana to the east to Salakan (Peling Island) and to the south to Banggai Island. Similarly, Bajo people migrate in groups to Banggai Island, as it is considered a safer area over wind and waves. Generally the Bajo people who settled in the Banggai Islands came from Bajoe (Bone). They made the voyage to Banggai Island to the east through Kabaena Strait, then to Tioro Islands to Kolo (Baturube) and to Tanjung Butung northward to Salabangka and then to Tolo Bay to Kalumbatang Island and partially spread to Kalupapi (Bangkurung Island) to Banggai Island. In addition to the shipping line, they also have a network of boat-making places such as Kolo (Baturube), Kolonodale, Bungku, Salabangka (Kalerowa), Banggai Laut (Kende '), and Salakan (Bonggana).

\section{Dynamics of Inter-island Trade}

Banggai geographic location in strategic shipping and trading lanes is between Ternate, Tomini Bay, Buton, and Makassar as a trading center. This path is the most important strategic or amenity road in the context of transportation and inter-island communication as well as trading network in an integrated maritime world and related economically-politically (Henley, 1993; Warren, 1979). Banggai trade relations with the Archipelago's traders were more focused on shipping and inter-island trade. The availability of various commercial commodities in Banggai, such as iron products and sea cucumbers that were almost annually produced have encouraged the emergence of inter-island trade network in the Archipelago (Henley, 2005: 457-458).

In the Maluku Islands region as a spice-producing region such as cloves and nutmegs, they have attracted Banggai to establish trade relations or commodity exchange, one of which was the Hoamoal Kingdom in Seram Island. The relationship between Banggai and 
Hoamoal in the context of the exchange of local commodities has been going on since the $16^{\text {th }}$ century and still persists to this date (Handoko, 2013: 45). The spice exporter kingdoms in Maluku acquired iron products and weapons from Banggai such as iron axes, machetes, swords, and knives. At the end of the $16^{\text {th }}$ century, important ports in eastern Sulawesi were controlled by Ternate including Banggai (Amal, 2010: 6; Reid, 1992: 125). Every year Banggai paid tribute to Ternate (ANRI, 1980: 24).

Iron products in the form of iron axes, swords, and machetes were brought in large quantities to Ternate (Pires, 2014: 299-300). In addition, copper and lead products appeared to be under the control of Bugis and Makassar merchants who marketed them to Ternate (Meilink-Roelofsz, 2016: 96; Pelras et al., 2006: 144). Some production of iron axes, swords, and knives were also brought to Ambon (Meilink-Roelofsz, 2016: 214). In addition to lead and copper, turtle skin was also a fancy commodity trade (Pelras, 2011: 18). The trading network of Bugis traders was a trade line passing through various ports. Bugis merchants anchored in a port to collect commodity products as well as the point of departure of their trade to main ports of the Archipelago and Singapore. Bugis Traders in the north and central Sulawesi Island carried gold dust, sandalwood, bird's nest, and turtle shell. After returning from Singapore, they carried Chinese opium, ceramics, Chinese kitchenware, Chinese raw silk, European wool cloth, and other commodities (Pelras et al., 2006: 362).

Banggai experienced developments in shipping and trading lines which then attracted Ternate to master it.

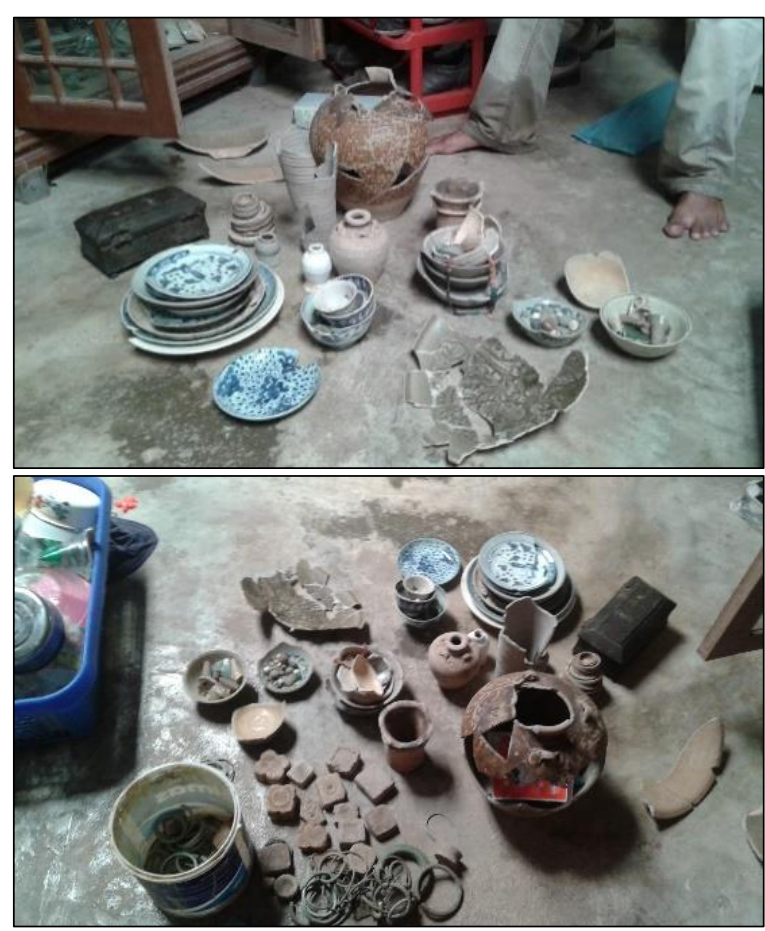

Figure 3. The remains of pottery and ceramics on Banggai Island

(Source: Author, 2015)
Although under the control of Ternate, Banggai continued to be influenced by the political and economic interests of Bone and Gowa. Bugis traders who often visited the coast of Banggai, they were considered to disturb the power of Ternate. Similarly, for Tobungku in the suburbs of Ternate, it received attention from the Dutch colonial and was referred to as an area of 'the dream of smugglers.' Bugis merchant from Malacca came to the port of Tobungku, known as a slave producer (Warren, 1998). Commodities of spices, turtle shells, candles, tobacco, and many other products were marketed at lower prices. When the Dutch colonial was short of merchandise in turtle shells, Tobungku became a supplier of quality turtle shells, particularly imported from Togian and Banggai Island (Andaya, 2015: 96; Meilink-Roelofsz, 2016: 96).

The Banggai Islands are also rich in quality timber species, including sandalwood that occupies a prime position in trade. In addition, there are types of wood suitable for building houses and boats, similar to the type of wood from the Tombuku area. Products of wood or ebony (meloegottan wood), kemoeni and gaharu wood are also in great demand by traders (Bosscher \& Matthijssen, 1854: 99). In Peling Island, there were found many mica products; coconut trees for copramaking materials; sago and rice were also found in large quantities in Balantak; resin, rattan, and wax produced from the southern villages; and in Pulau Salui there was bird's nest. Since the discovery of gold content, it attracted the miners to carry out the exploration (Paulus, 1917: 139).

Products of sea cucumbers were obtained from islands with a large number. Each year the catch of sea cucumbers reaches 800 to 900 pikul, as well as other commodities such as turtle scales, bird's nests, and forest products for trading. The trading system is entirely under local rulers, as sea cucumbers and turtle scales do not enter Banggai, but exported directly to Singapore. The merchants pay only the fish tax, of which income is halved for Ternate and the other half is given to local rulers/kings (Bosscher \& Matthijssen, 1854: 91). The high demand for trade commodities in Banggai led to competition from rulers and traders to dominate trade commodities. The expansion of Ternate to the west of the Banggai Islands, the eastern coast of Sulawesi, even to the north of Sulawesi (Pattikayhatu, 2012: 6), Gorontalo and Bolaang Mongondow has not only given the naming of the royal bureaucracy, such as jogugu, bobato, kapitanlaut, sangaji, and so on, but also the spread of Islam and the expansion of trade networks (Handoko, 2017: 98-99).

In the next decade, the dynamics of trade occurred in the Banggai region has led to the dynamics of economypolitics within the region. Banggai which was a vase of Ternate then became an important area for the Dutch 
colonial and Bone. The power of Ternate over Banggai decreased after the Ternate authorities in Banggai affairs often gained control from the Dutch colonial. The Dutch intervention can be a counterweight to the actions of Ternate that incriminate Banggai residents. Memories of Tobias reported that the new Banggai was able to deliver the offerings to Ternate after three years of supposed annually-delivered tribute. This is because the Banggai ruler was unable to get a boat and the crews who can carry tribute to Ternate, it was also the Banggai resident reluctance to deliver the tribute, because thus far people who deliver tribute were usually held captive in Ternate. They were employed in other jobs to fill the labor shortage in Ternate (ANRI, 1980: 11-12).

Bone traders who initially had only economic interests (trading), then turned into political interests (power) in Banggai. This factor was supported by the strategic location of Banggai as the northern trade route (Ternate), to the south (Makassar) must pass or transit at Banggai port. In addition, Banggai was a place to accommodate trade commodities from the surrounding areas (city periphery) such as Tombuku, Peling, Taliabu Island, Sula, and Togian Islands. The Bone traders tried to influence and support Raja Banggai's resistance to unleash the power of Ternate. Bone's interest aims to expand its hegemony in Mendono, Banggai, Buton, and Kendari in order to protect its shipping and trading lanes in eastern Sulawesi (de Jong, 2011: 60). It emerged the opposition from the Banggai Kings over the penetration of political and economic power built by the sultanate of Ternate and the Dutch colonial government, even influence of the expansion of the Bone kingdom trade can even be controlled through the Ternate forces (Velthoen, 2002: 16). In this case, Banggai along with Tobungku local forces have confirmed the existence of a military alliance with Bugis (Velthoen, 2002: 26).

In 1829, King Atondenga titled as mumbu doi Galela had opposed against the Sultan of Ternate, Muhammad Zain. King Atondenga refused the payment of tribute and expelled the envoy of the Sultan of Ternate. Some Bugis people, led by Daeng Mangajae, and heads of the state (basalo or basanyo) supported the actions of King Atondenga. Then all the heads of the state retreated, except Basanyo Batui who continued to help the resistance. Once the Tobelo people were known to help Ternate, Basanyo Batui and his followers fled for their lives when Ternate troops and the reinforcements from Tobelo approached Banggai Island. Eventually, King Atodenga escaped and was arrested in Mendono, then was exiled to Ternate and died in Galela (Clercq, 1890: 175; Dormeier, 1947: 182).

Even in November 1840, the rivalry between the Ternate and Bugis increased, after the envoys and all Ternate troops in Tobungku were killed by the people on the orders of King Tobungku, Dongke Kombe. Kombe rebellion arose after receiving assistance from two Bugis nobles, they were Daeng Mangkala and Daeng Palili. The Sultan of Ternate had attacked in mid-1842 and succeeded in ruling over Tobungku (Kartodirdjo, 1973: 344).

In October 1846, the rebellion took place when King Banggai, Agama titled as mumbu doi Bugis got help from the Bugis people in Kendari and Togian. King Agama rejected the request of the envoy of Sultan of Ternate with the force of two Kora-kora troops to fetch him to Ternate. In February 1847, there was a war in the sea between the forces of King Agama assisted by the Bugis against the Ternate forces using kora-kora. Finally, Banggai troop can be conquered, King Agama along with Bugis people fled to Tojo. In April 1847, Sultan of Ternate sent his expedition with the kora-kora fleet to Tojo to capture King Agama. Having known the arrival of Ternate troops, King Agama continued his escape to Buton and appealed for protection to Arung (king) Bone, La Parenrengi Arung Ugi (Clerq, 1890: 178; de Jong, 2011: 57-58; Kartodirdjo, 1973: 345).

In 1880, traders from Mandar began to actively trade in Banggai. Every Mandar dealer was charged with an anchor or port tax which was an income of a representative of Sultan of Ternate in Banggai (Dormeier, 1947: 133). Arabian traders had trade cooperation with King and Banggai nobles. They usually exchanged goods by barter through sangaji (village chief) as a royal representative on the coastal area (ANRI, 1980: 147148). In addition, Chinese traders from Gorontalo traded to Banggai. They generally purchased forest products, especially resin and rattan which were then transported to Gorontalo. Subsequently, a contract was established to regulate the logging and transportation of timber for land processing. Similarly, coffee as the main product was generally purchased by the Bajo, Chinese, and Gorontalo people (ANRI, 1883).

The Government of the Netherlands East Indies issued a political policy in arranging voyages to protect its merchant ships from competition with European ships, as well as Bugis, Makassar and Mandar boats. This policy benefited the ships owned by Dutch businessmen or Koninklijke Paketvaart Maatschappij (KPM) which dominated the shipping and transportation of goods. The inter-island copra trade was initially controlled by Bugis merchant boats, but following the Dutch Indies Government issued its KPM monopoly policy, the traders began to turn their attention to KPM. Chinese merchants prefer KPM as they were able to transport copra in large quantities and faster times. Although KPM had shipping monopoly, but the voyages controlled by Bugis remained to be KPM rivals. Several Bugis and Makassar boats originally occupied commercial voyages were slowly transporting copra in a relay. The interisland transport monopoly by Bugis traders formed an 
increasingly strong network following the advent of copra trade. Trading activities for Bugis and Mandar traders were made easier by the influence of the power of Bugis and Mandar traders in the Tomini Bay area. KPM voyage (line 21) served the route along southern and eastern coast of Sulawesi via Buton Strait - Tumori Bay - Kolonadale - Banggai - Gorontalo took within four weeks from Makassar (Asba, 2007: 101).

The beginning in 1895, the Sultan of Ternate issued a policy by offering to European trading business in Gorontalo to remove monopoly trade right for logging and transporting timber. The aim was to liberate logging by the population, for the purposes of shipbuilding and houses construction, and to meet the needs of the Sultan. In addition, the right to collect forest products for each buyer can make an agreement according to the price of concession in excise tax offered through the contract to the Sultan, i.e. $f 1,000$ per year. Excise tax resulted in wood product contracts for 15 years were granted to King Banggai and his nobles of conquests by 20 per cent (ANRI, 1883). Following 1906, the Kingdom of Banggai was under Dutch colonial rule. The transition of power led to all pearl shell products, and monopoly rights of other marine products in Banggai waters were controlled by the Dutch colonial (Paulus, 1917: 139).

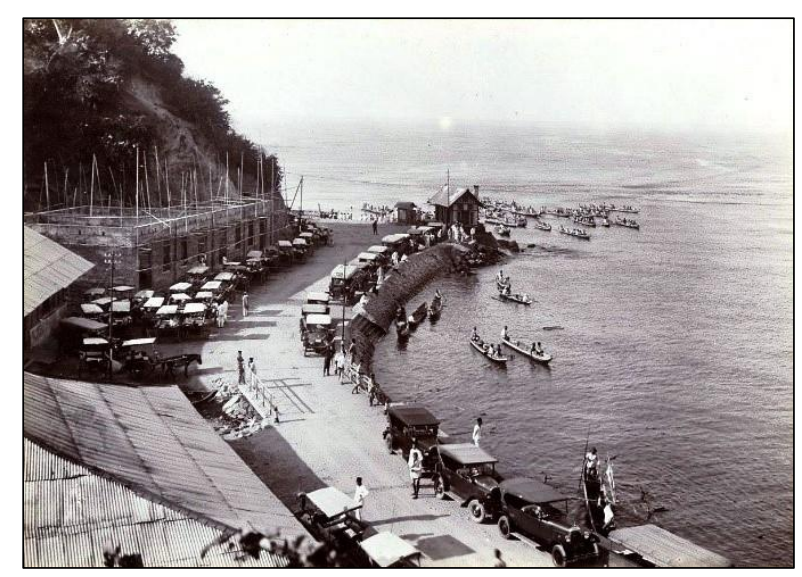

Figure 4. Dock of Luwuk Port in Banggai, 1926

(Source: Sumber: Tropenmuseum- TM30004041)

\section{Pirate}

Banggai had a decent port, safe hideouts and there were many secret shipping or smuggling lanes that can be used among the islands, thus attracting pirates to build their hiding places. Although the Dutch colonials had placed a lieutenant as a civilian gezaghebber with several soldiers and had the authority to quell the pirates, it was unable to destroy the pirates. This was due to the absence of a means for gezaghebber such as ship to destroy the pirates in retaining his power (Het Nieuws van den Dag voor Nederlandsch-Indië, 29 Januari 1910: 2).

Pirates who did piracy in the waters of the Banggai Islands was pirates Tobelo, Mangindanao, and Solokh (ANRI, 1980: 135-136). The most famous pirate of the $19^{\text {th }}$ century was the Tobelo from North Halmahera. The area of Tobelo piracy was vastly extensive including Flores Sea, Banda Sea, Maluku Sea, Tomini Bay (Gorontalo), Banggai Islands, Tobungku, and Butung or Buton Islands (Lapian, 2008: 183). Banggai were often targeted by pirates of Tobelo up to the inland by looting and burning human settlements. In order to overcome their attacks, in the regional centers both on the island and the mainland, a fortress was built up surrounded by stone walls. Having acknowledging the arrival of pirates Tobelo, the inhabitants were put into the fortress, while men served as a defense in the face of pirates Tobelo's attack. Almost all the attacks by pirates Tobelo managed to defeat the resistance of inhabitants in the villages, that a number of residents were captured and made into slaves. Although there were soldiers in some areas, such as Batui, Tangkian, Kintom, and Mendono numbered about forty soldiers and some officers, but they were not specifically reserved for the defense in the area. They were more dedicated to handle important events, such as religious festivals and other parties. Defense tasks in hazardous conditions were imposed on all men who were ready for battle (Dormeier, 1947: 180).

In 1820, due to the pressure of Dutch warship patrols, the pirates Tobelo made a partnership with the Mindanao sea pirates who possessed hiding places and logistics (Velthoen, 1997: 204). In their expedition, there were 4 or 5 Tobelo pirate boats that can accommodate up to 10 people. For more important or large expeditions, several small boats were bound together to form larger troops under the command of a leader. In 1870 , there were 48 Tobelo pirate boats operating in Tomini Bay. They were then splitted into smaller groups and spread to the eastern sea of Sulawesi (Velthoen, 1997: 214).

A series of Raja Banggai rebellions against the Sultan of Ternate and the formation of the Mindanao and Tobelo coalitions as pirate colonies, made the eastern coast of Sulawesi as a dangerous area in the first half of the $19^{\text {th }}$ century. In 1850 , Van der Hart circled the island and the entire coastal area from Kendari to Balantak and seemed to find completely empty houses, the residents were fleeing to the inland or elsewhere. In the same year, Revius visited the open border of Tomori Bay and discovered a newly founded village (Henley, 2005: 246).

Piracy and captivity of the inhabitants into slavery clearly influenced the settlements around the coastal area (George, 1991; Warren, 1998). Many people left the Tomini area to the coast of Gorontalo in order to seek protection and safety from the pirate attacks. In general, people stayed away from building settlements on the coastal area as it had links to slave robbers (Henley, 2005: 430-431). In Balantak, Tobelo pirate activities often captivate residents for slavery. Afterwards, the arrival of Tobelo pirate got resistance from Balantak residents. The emergence of various resistance of the 
residents resulted in Tobelo pirates rarely entered Balantak area. Pirate's reputation in Banggai in oral tradition of the surrounding kingdoms, though it can be estimated that pirates in the Banggai area were not local residents, but their reputation for cruelty was well known in the surrounding region. The Kingdom of Buton, for example, in oral tradition was stated to be very frightened of the figure of La Bolontio pirate who lived in Banggai (Couvreur \& Van Den Berg, 2001: 7).

\section{Merchant and Migrants Settlement}

It should be noted that the trade political conditions in Banggai and the strategic geographic location of transit sites indicates that contestation encouraged migration of local people into mainland areas and generated settlements based on traders and migrants. This took place despite having a strategic geographical position, the economic-political conditions as a result of the emergence of alliances that occurred due to trade competition between local people with colonial power and the surrounding empires affected the presence of settlements. In the early $19^{\text {th }}$ century, during the official visit of colonial officers, some settlements in Banggai were found to have been abandoned and moved to the mainland due to attacks from both pirates and political and military forces that the numbers of population in the eastern coastal areas had declined. It was then clarified that following the failed resistance against the Netherlands and Ternate in the decade of 1840s, there had been relocation of settlements into more relatively protected areas from any attack of foreigners, including leaving the settlement due to the disease outbreaks (Velthoen, 2002: 24).

Over the next decade, Banggai's abandoned but strategically located area of trade transit routes, besides the availability of fertile soil and producing valuable commodities, had attracted traders to Banggai. Some traders who established settlements such as Bugis, Buton, Gorontalo, Bajo, China, and Arabs gained tremendous potential in developing trading businesses by utilizing shipping and trading networks. The traders and settlers who lived in Banggai include the Bugis and Gorontalo colonies that established a village with self-government and self-help. Bugis and Gorontalo colonies were scattered throughout the Banggai region and generally settled in coastal areas. The Bugis colony has family ties with Bugis people from Wani, Palu, and Gorontalo. In addition, settlements for Bajo people settled in Tinakun (Banggai Island), mostly settled in Kalumbantang (east coast of Peling) and Pagimana in Tomini Bay (Dormeier, 1947: 46-47). They settled in pillared houses over the sea with their own leaders and customs. The Butonese generally came from the Muna and only arrived as seasonal workers. They occasionally stayed for only a few months or chose to stay for a few years in a village and worked as coconut pickers or small traders (Dormeier, 1947: 7-8).

Bugis, Gorontalo, Buton, and Bajo people were given the freedom to organize their communities in every settlement. For years, Bugis immigrant groups from Bunta gained recognition from the Government of the Netherlands East Indies as subordinate districts (subdistricts) and led by a head of the kapitan (Andaya, 1995). Moreover, for the Bajo village under its own leadership titled as punggawa occupied their typical homes over the sea. The Gorontalo people established their own villages by choosing their leader with title of major (lower than kapitan). In Bunta there is a major of Gorontalo under the rule of a Bugis kapitan. The village head election for the Bugis colony was based on the descendants of the founding village with title of kapitan lolo, and in charge of several heads called matoa. In addition, each Gorontalo village in Boalemo and Pagimana was led by a major. The settlement of the Saluan people is under the leadership of a kapala kampong (Dormeier, 1947: 82; 128).

Buginese colonies were scattered in the Banggai region, and generally settled in coastal areas. For Banggai people, they call them Bungin people, rather than To Ugi like most in the overseas. Bugis traders were given a territory by Jogugu Banggai to establish settlements and developed into Kampung Bugis, by selfgovernment and self-help. They were given with the freedom to organize their own community, and around Bugis Village there are also Buton, Bungku, and Gorontalo Village (now becomes Tanjung, Lompio Village). In 1840, around 100 to 150 Bajo (soppe) boats entered the waters of the Banggai Islands and spread to Peling Island, Banggai Island, and the islands of the southeast. An important fact for local rulers was that they were very dependent on Bajo people who mostly carried exporting commodities in inter-island trade. Coral fish was only intended for their own income, while dried fish

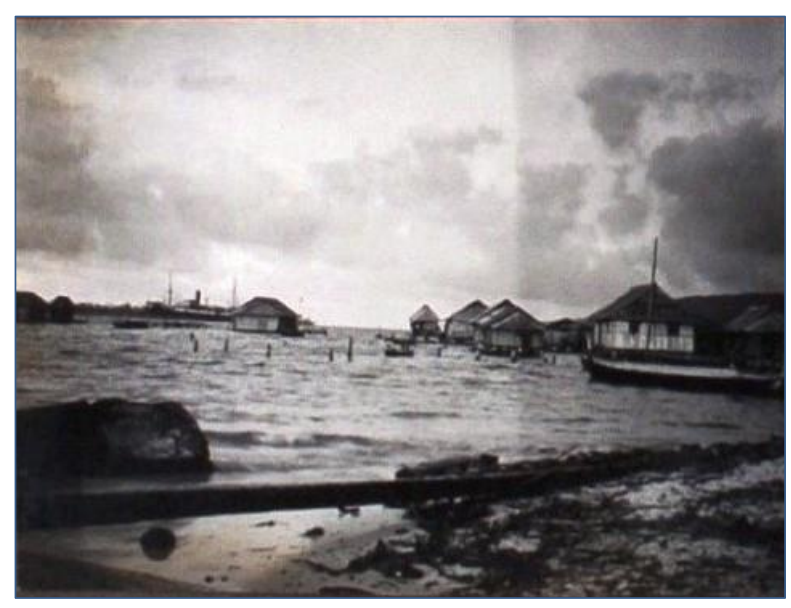

Figure 5. Houses over the sea in Banggai Islands with steamship S.S. Spilbergen in the background, 1926 (Source: Sumber: Tropenmuseum-TM30004043) 
was bartered with daily goods. Commodities such as sea cucumbers, turtle shells, and shark fins were exported to the Chinese market (Sopher, 1965: 149). Most of the Bajo people lived exclusively on the waters with a fairly large boat called padewakang, where the children were born and were raised in their lives (Sopher, 1965: 212).

The life of the Bajo colony in Kalumbatan (east coast of Peling Island) is under their autonomous power titled punggawa with its own custom. The number of Bajo people was about 300 to 400 inhabitants. The Bajo wanderers make settlements along the east coast of Sulawesi to the Togian Islands. They were charged to pay a fish tax of $f 4$ each year to the Sultan of Ternate (Clercq, 1890: 132). They have their main livelihood as a sea cucumber and pearl shell hunter which then became an export commodity (Paulus, 1917: 139). Kampung Bajo in Pagimana was more oriented to the power of Bone. They settled with architectural pillared houses over the sea (Dormeier, 1947: 46-47). Until the early $20^{\text {th }}$ century, the Bajo people did not pay taxes to the Dutch colonials, but instead sent tribute to King Bone. Similarly, Bajo people in the Banggai Islands who recognized the power of King Bone, but were required to pay coral taxes to the envoy of the Sultan of Ternate based in Banggai (Lapian, 2011: 155). Every year the Bajo people paid taxes of $f 1$ to the Sultan of Ternate, as the right to catch fish in the waters of Banggai. In addition, they were also required to pay $f 4$ taxes per boat and $f 2$ per house in order to perform their daily activities (Dormeier, 1947: 134).

\section{Conclusion}

The strategic geographical location in the eastern part of Sulawesi Island and the Maluku Sea, Tomini Bay and Tolo Bay/Banda Sea as Ternate, Buton and Makassar shipping lanes provide advantages for Banggai as a shipping transit area. Its shipping and trading networks have been hectic even since the $14^{\text {th }}$ century, for this factor is also driven as an iron ore producer which is one of the main trading commodities. Even in the $16^{\text {th }}$ century, iron export trade had been controlled by Banggai. Similarly, sea cucumber (teripang), sea turtle scales, bird nest, shell, wood, and then copra make Banggai an important area in trade. The arrival of Bugis traders, Gorontalo, Buton, Bajo, Mandar, Ternate, China, and other foreign traders brought progress in Banggai trade. The impact of Banggai's trade progress has resulted in business and power competition between Ternate and Bone that directly affect the political dynamics of Banggai.

Banggai shipping and trading is an important factor in moving the connecting lines of ports and shaping the dynamics of eastern Sulawesi. In the network it also took place communication of traders who come from various ethnic groups that settled and established the village in Banggai. Formation of shipping networks becomes an integral factor in both inter-island connection and formation of 'new' communities derived from diverse regional origins.

\section{ACKNOWLEDGEMENT}

The author would like to thank all those who helped in this research. Thanks to the Head of Cultural Values Conservation Center, Banggai Laut community leaders, Banggai Islands, and Luwuk for the time and opportunity provided during the research. Thanks also to Kapata Arkeologi who has published this research.

$* * * * *$

\section{REFERENCES}

Abdurrahman. (2012). Sejarah Kesultanan Banggai. Jakarta: Puslitbang Lektur dan Khazanah Keagamaan Badan Litbang dan Diklat Kementerian Agama RI.

Amal, M. A. (2010). Kepulauan Rempah-rempah Perjalanan Sejarah Maluku Utara 1250-1950. Jakarta: Kepustakaan Populer Gramedia (KPG).

Andaya, L. Y. (1995). The Bugis-Makassar Diasporas. Journal of the Malaysian Branch of the Royal Asiatic Society, 68(1 (268), 119-138.

Andaya, L. Y. (2015). Dunia Maluku Indonesia Timur Pada Zaman Modern Awal. Yogyakarta: Ombak.

ANRI. (1883). Koloniaal Verslag, van 1883 dan 1896. Jakarta: Arsip Nasional Republik Indonesia.

ANRI. (1976). Inventaris Arsip Gorontalo, 1810-1865. Jakarta: Arsip Nasional Republik Indonesia.

ANRI. (1980). Ternate Memorie van Overgave, JH Tobias (1857), Memorie van Overgave, C. Bosscher (1859). Penerbitan Sumber-Sumber Sejarah, (11).

Asba, A. R. (2007). Kopra Makassar Perebutan Pusat dan Daerah: Kajian Sejarah Ekonomi Politik Regional di Indonesia. Jakarta: Yayasan Obor Indonesia.

Bosscher, C., \& Matthijssen, P. A. (1854). Schetsen van de rijken van Tomboekoe en Banggai, op den oostkust van Celebes. In Tijdschrift voor Indische Taal-, Land- en Volkenkunde (TBG), II.

Couvreur, J., \& Van Den Berg, R. (2001). Sejarah dan Kebudayaan Kerajaan Muna. Artha Wacana Press.

Clercq, F. S. A. (1890). Ternate: The Residency and its Sultanate. In Bijdragen tot de kennis der Resindetie Ternate. Leiden: E.J. Brill.

de Jong, C. G. F. (2011). Nieuwe hoofden Nieuwe goden: Geschiedenis van de Tolaki en Tomoronene, twee volkeren in Zuidoost-Celebes (Indonesië), tot ca. 1950. Saarbrücken: Lambert Academic Publishing.

Dormeier, J. J. (1947). Banggaisch Adatrecht. In Verhandelingen van het Koninklijk Instituut voor Taal-, Land- en Volkenkunde (VKI), VI. 's-Gravenhage: Martinus Nijhoff.

Frederick, W. H., \& Soeroto, S. (1984). Pemahaman Sejarah Indonesia: Sebelum dan Sesudah Revolusi. Jakarta: LP3ES. 
George, K. M. (1991). Headhunting, History, and Exchange in Upland Sulawesi. The journal of Asian studies, 50(3), 536-564.

Gottschalk, L. (1986). Mengerti Sejarah. In Nugroho Notosusanto (Ed.). Jakarta: UI Press.

Handoko, W. (2013). Gerabah Situs Wayputih sebagai Komoditi Barter di Kerajaan Hoamoal. Kapata Arkeologi, 9(1), 37-50.

Handoko, W. (2017). Ekspansi Kekuasaan Islam Kesultanan Ternate di Pesisir Timur Halmahera Utara. Kapata Arkeologi, 13(1), 95-108.

Henley, D. (1993). A Superabundance of Centers: Ternate and the Contest for North Sulawesi. Cakalele, 4, 39-60.

Henley, D. (2005). Fertility, Food and Fever: Population, Economy and Environment in North and Central Sulawesi, 1600-1930. Leiden: KITLV.

Het Nieuws van den Dag voor Nederlandsch-Indië. (1910). Rondom Celebes. Het Nieuws van den Dag voor Nederlandsch-Indië, January 29, 1910, p. 2.

Kartapranata, G. (2008). Trade route map of Southeast Asia around 12 th to early 13 th century AD. Retrieved June 10 , 2018, from http://en.wikipedia.org

Kartodirdjo, S. (1973). Ikhtisar Keadaan Politik HindiaBelanda Tahun 1839-1848. Jakarta: Arsip Nasional Republik Indonesia.

Kartodirdjo, S. (1993). Pengantar Sejarah Indonesia Baru: 1500-1900: Dari Emporium Sampai Imperium. Jakarta: Gramedia Pustaka Utama.

Kartodirdjo, S. (2014). Pendekatan Ilmu Sosial Dalam Metodologi Sejarah. Yogyakarta: Ombak.

Kuntowijoyo. (1995). Pengantar Ilmu Sejarah. Yogyakarta: Bentang Pustaka.

Kusumoprojo, W. S. (2009). Indonesia Negara Maritim. Jakarta: Mizan Publika.

Lapian, A. B. (1987). Orang Laut-Bajak Laut-Raja Laut: Sejarah Kawasan Laut Sulawesi Abad XIX. Doctoral Dissertation Universitas Gadjah Mada.

Lapian, A. B. (2008). Pelayaran dan Perniagaan Nusantara Abad Ke-16 dan 17. Jakarta: Komunitas Bambu.

Lapian, A. B. (2011). Orang Laut, Bajak Laut, Raja Laut: Sejarah Kawasan Laut Sulawesi Abad XIX. Jakarta: Komunitas Bambu.

Meilink-Roelofsz, M. A. P. (2016). Persaingan Eropa \& Asia di Nusantara, Sejarah Perniagaan 1500-1630. Jakarta: Komunitas Bambu.

Pattikayhatu, J. A. (2012). Bandar Niaga di Perairan Maluku dan Perdagangan Rempah-Rempah. Kapata Arkeologi, 8(1), 1-8.

Paulus, J. (1917). Encyclopaedie van Nederlandsch Indie, eerste deel.'s. Gravenhage: Martinus Nijhoff.

Pelras, C., Abu, A. R., \& Arsuka, N. A. (2006). Manusia Bugis. Jakarta: Nalar \& Forum Jakarta-Paris École francaise d'Extrême-Orient.

Pelras, C. (2011). Sulawesi Selatan Sebelum Kedatangan Agama Islam Mengikut Sumber-Sumber Asing Terawal. Jurnal Terjemahan Alam \& Tamadun Malayu, 3(1), 1340).

Pires, T. (2014). Suma Oriental. Yogyakarta: Penerbit Ombak.

Reid, A. (1992). Asia Tenggara Dalam Kurun Niaga 1450 1680 Jilid 1. Jakarta: Yayasan Pustaka Obor Indonesia.

Reid, A. (2008). Merchant Princess and Magic Mediators: Outsiders and Power in Sumatra and beyond. Indonesia and Malay World, 36(105), 253-267.

Riana, I. K. (2009). Kakawin Desa Warnana Uthawi, Nāgara Krtāgama, Masa Keemasan Majapahit. Jakarta: Kompas.

Rochayati, S. (2010). Jatuhnya Benteng Ujung Pandang, Makassar Pada Belanda (VOC). Thesis Universitas Sebelas Maret Surakarta.
Schouten, M. J. (2004). Manifold Connections: The Minahasa Region in Indonesia. South East Asia Research, 12(2), 213-235.

Sopher, D. E. (1965). The Sea Nomads: A Study Of The Maritime Boat People of Southeast Asia. Singapore: National Museum Singapore.

Velthoen, E. J. (1997). Wanderers, Robbers and Bad Folk': the Politics of Violence, Protection and Trade in Eastern Sulawesi 1750-1850. In A. Reid (Ed.), The Last Stand of Asian Autonomies. Studies in the Economies of East and South-East Asia (pp. 367-388). London: Palgrave Macmillan.

Velthoen, E. J. (2002). Contested Coastlines: Diasporas, Trade and Colonial Expansion in Eastern Sulawesi 1680-1905. Doctoral Dissertation Murdoch University.

Warren, J. F. (1979) The Sulu Zone: Commerce and the Evolution of a Multi-Ethnic Polity 1768-1898. Archipel, 18, 223-230.

Warren, J. F. (1998). Southeast Asia. In S. Drescher \& S. L. Engerman (Eds.), A Historical Guide to World Slavery (pp. 80-87). Oxford: Oxford University Press.

Zuhdi, S. (2010). Sejarah Buton yang Terabaikan Labu Rope Labu Wana. Jakarta: Rajawali Rajagrafindo.

Zuhdi, S. (2014). Nasionalisme, Laut, \& Sejarah. Depok: Komunitas Bambu. 